\section{Development ceramic floor tiles with increased shear and pressure strengths}

LÁszLó A. GÖMZE - Institute of Ceramics and Polymer Engineering, University of Miskolc • femgomze@uni-miskolc.hu

SERGEI N. KULKOV - Institute of Strength Physics and Materials Science SB RAS, National Research Tomsk State University - kulkov@ms.tsc.ru

EMESE KUROVICS - Institute of Ceramics and Polymer Engineering, University of Miskolc, Miskolc • fememese@uni-miskolc.hu

ALES S. BUYAKOV - Institute of Strength Physics and Materials Science SB RAS, National Research Tomsk State University - alesbuyakov@gmail.com

AleXANDR Y. BUZIMOV - Institute of Strength Physics and Materials Science SB RAS, National Research Tomsk State University - buzimov92@gmail.com

MiHAIL V. GRIGORIEV - Institute of Strength Physics and Materials Science of RAS, Tomsk Polytechnic University - grv@ispms.ru

BronisLAV I. KANEV - Institute of Ceramics and Polymer Engineering, University of Miskolc - slava.kanev.1995@mail.ru

TATIANA V. KOLMAKOVA - Institute of Strength Physics and Materials Science SB RAS, Tomsk State University • kolmakova@ftf.tsu.ru

RUSLAN V. LEVKOV - Institute of Strength Physics and Materials Science of Siberian Branch of Russian Academy of Sciences, National Research Tomsk Polytechnic University • levkov.r.v@mail.ru

SERGEY A. SITKEVICH - Institute of Ceramics and Polymer Engineering,

University of Miskolc - sitx0113@yandex.ru

Érkezett: 2018. 01. 15. - Received: 15. 01. 2018. - https://doi.org/10.14382/epitoanyag-jsbcm.2018.3

\section{Abstract}

In the present research work is studied and described the influence of alumina and zirconia powders on physical and mechanical properties of the conventional ceramic floor tiles. After testing several different raw material compositions the authors have found that adding $5 \mathrm{~m} \%$ commercial $\mathrm{ZrO}_{2}$ powders the shear strengths and pressure strengths of these floor tiles can be considerable increased. These new floor tiles with increased mechanical strengths may be suitable for use in dairy, meat, food and other industries.

Keywords: alumina, ceramics, compacting, density, floor tiles, mixtures, powders, zirconia
László A. GÖMZE,

Establisher (in July 1st, 1999) of the Department of Ceramics and Silicate Engineering in the University of Miskolc, Hungary. He is author or coauthor of 2 patents, 6 books and about 300 scientific papers. Recently, he is the chair of the International Organization Board of ic-cmtp5 the 5 th International Conference on Competitive Materials and Technological Processes (2018) and ic-rmm3 the 3rd International Conference on Rheology and Modeling of Materials (2017)

Sergei N. KULKOV, is head of Department of Ceramics in the Institute of Strength Physics and Materials Science of the Russian Academy of Science Author of 5 books, more than 150 articles and 18 patents.

Emese KUROVICS, Graduated in the University of Miskolc, Department of Ceramics and Silicate Engineering as a material engineer, where she actually continues her study as PhD student under supervision of Prof. L. A. Gömze.

Ales S. BUYAKOV, is a master student at Tomsk State University. He has several reports on international conferences including Junior EuroMAT-2014.

Alexandr Y. BUZıMoV, PhD student in the Institute of Strength Physics and Materials Science of the Russian Academy of Sciences in Tomsk

Mihail V. GRIGORIEV, (2014) PhD has finished the Polytechnical Institute of the Siberian Federal University in 2007. At present time he is a post-doctoral fellow in Institute of Strength Physics and Materials Science of Siberian Branch of the Russian Academy of Science under guidance Prof. Kulkov. Topic of his PhD. work was "Features of

\section{Introduction}

The ceramic floor tiles are widely used as building materials both for interior architectural purposes in the living and public buildings and for hygiene purposes in the dairy, meat, food and other industries [1-2]. Because of this circumstance there are several research works which are studying, analyzing and describing the physical, chemical, thermal, acoustic and morphological properties both of the used raw materials and the sintered glazed or unglazed floor tiles [3-12]. Generally the production lines of wall and floor tiles industry are used fast drying and sintering technology with roller furnaces of less than 50 minutes cold to cold firing cycle. Because of this fast heating and cooling the green bodies of tiles are very sensitive to the diffusion of water vapor and heating curve in the beginning part of the fast firing roller kilns.

The beautiful designed wall and floor tiles which are excellent in the living and public buildings usually cannot be used in the industrial workshops, storage pools, silos and reservoirs because of the shortages of their durability and mechanical strengths. It can be possible to increase the mechanical strengths through increment of sintering temperature [13] but this is not so easy because of the low melting temperature of deformation and fracture of porous alumina ceramics based on nanopowders"

Bronislav I. KANEV, is graduated master's courses at the Syktyvkar State University named after P. Sorokin in the specialty Geology. At present he is a PhD student at University of Miskolc under supervision of Prof. L. A. Gömze.

Tatiana V. KOLMAKOVA, lecturer PhD in the Tomsk State University

Ruslan V. LEVKOV is graduated in the National Research Tomsk State University. At present he is working in the Institute of Strength Physics and Materials Science SB RAS.

Sergey A. SITKEVICH, is graduated master's courses at the Syktyvkar State University named after P. Sorokin in the specialty Geology. At present he is a PhD student at University of Miskolc under supervision of Prof. L. A. Gömze.

some of the components of the used pulverized powder-mix raw materials. Generally it is possible to get ceramic products with increased mechanical strengths trough composite material structures [14-18]. Our aims are to increase the mechanical properties and durability of the ceramic floor tiles used in food and chemical industries by creating a new ceramic composite structure adding ceramic powders with increased mechanical 
strengths, hardness and durability to the conventional raw materials as pulverized floor tile powders.

\section{Materials and experiments}

In the last 10-15 years ceramics and ceramic matrix composite materials (CMC) are widely used because of their low density and excellent wear resistance, hardness, toughness and mechanical strength [19-24]. Really the most widely used and popular technical ceramics [25-33] have relatively low density and very competitive mechanical properties (Table 1).

\begin{tabular}{|c|c|c|c|c|c|c|}
\hline $\begin{array}{l}\text { Type of } \\
\text { ceramics }\end{array}$ & $\begin{array}{l}\text { Den- } \\
\text { sity } \\
\mathrm{g} / \mathrm{cm}^{3}\end{array}$ & $\begin{array}{c}\begin{array}{c}\text { Tensile } \\
\text { strength }\end{array} \\
\text { MPa }\end{array}$ & $\begin{array}{c}\text { Bending } \\
\text { strength } \\
\mathrm{MPa}\end{array}$ & $\begin{array}{c}\text { Com- } \\
\text { pressive } \\
\text { strength } \\
\mathrm{MPa}\end{array}$ & $\begin{array}{l}\text { Young } \\
\text { Modu- } \\
\text { lus } \\
\text { GPa }\end{array}$ & $\begin{array}{c}\text { Fracture } \\
\text { tough- } \\
\text { ness } \\
\text { MPam }^{1 / 2}\end{array}$ \\
\hline $\mathrm{Al}_{2} \mathrm{O}_{3}$ & 3.98 & 210 & 560 & 2800 & 392 & 5.5 \\
\hline SiC sintered & 3.1 & 175 & 560 & 3920 & 420 & 4.4 \\
\hline $\begin{array}{l}\mathrm{Si}_{3} \mathrm{~N}_{4} \text { reac- } \\
\text { tively bound }\end{array}$ & 2.5 & 140 & 245 & 1050 & 210 & 3.3 \\
\hline $\begin{array}{l}\mathrm{Si}_{3} \mathrm{~N}_{4} \text { hot } \\
\text { pressed }\end{array}$ & 3.2 & 560 & 910 & 3500 & 315 & 5.5 \\
\hline SiAION & 3.24 & 420 & 980 & 3500 & 315 & 9.9 \\
\hline $\begin{array}{l}\mathrm{ZrO}_{2} \text { partially } \\
\text { stabilized zir- } \\
\text { conia (PSZ) }\end{array}$ & 5.8 & 455 & 700 & 1890 & 210 & 11.0 \\
\hline
\end{tabular}

\section{$\mathrm{ZrO}_{2}$ trans-}

formation

toughened

$5.8 \quad 350$

$350-806$

$806 \quad 1750$

203

zirconia (TTZ)

Table 1. The mechanical properties of the most widely used technical ceramics

1. táblázat A leggyakrabban alkalmazott müszaki kerámiák mechanikai tulajdonságai

In the laboratory experiments were used conventional pulverized powder mixtures of floor tiles which were prepared from the following raw materials: clay Petény I and II, clay Teplicsány, rhyolite, conventional clay Kisőrs, GVZand phonolite. The mineralogical composition of these powder mixtures is described in the Table 2 and the typical microstructure and chemical components are shown in Figure 1.

\begin{tabular}{|c|c|c|}
\hline Minerals & Chemical composition & Quantity, m\% \\
\hline$\beta$-quartz & $\mathrm{SiO}_{2}$ & 22.51 \\
\hline a-quartz & $\mathrm{SiO}_{2}$ & 37.31 \\
\hline tridimite & $\mathrm{SiO}_{2}$ & 7.35 \\
\hline orthoclase & $\mathrm{K}(\mathrm{Al}, \mathrm{Fe}) \mathrm{Si}_{2} \mathrm{O}_{8}$ & 0.3 \\
\hline nepheline & $\begin{array}{c}3 \mathrm{Na}_{2} \mathrm{O} \mathrm{K}_{2} \mathrm{O} \\
4 \mathrm{Al}_{2} \mathrm{O}_{3} 9 \mathrm{SiO}_{2}\end{array}$ & 5.37 \\
\hline albite & $\mathrm{NaAl}_{3} \mathrm{Si}_{3} \mathrm{O}_{11}$ & 4.55 \\
\hline microcline & $\mathrm{KAl}_{3} \mathrm{Si}_{3} \mathrm{O}_{11}$ & 5 \\
\hline illite & $\begin{array}{c}2 \mathrm{~K}_{2} \mathrm{O} 3 \mathrm{MgO} \\
\mathrm{Al}_{2} \mathrm{O}_{3} 24 \mathrm{SiO}_{2} 12 \mathrm{H}_{2} \mathrm{O}\end{array}$ & 3.69 \\
\hline sanidine & $(\mathrm{Na}, \mathrm{K})\left(\mathrm{Si}_{3} \mathrm{Al} \mathrm{O}_{8}\right.$ & 2.89 \\
\hline glauconit-1 & $\mathrm{K}(\mathrm{Fe}, \mathrm{Al})_{2}(\mathrm{Si}, \mathrm{Al})_{4} \mathrm{O}_{10}(\mathrm{OH})_{2}$ & 3.32 \\
\hline sodium aluminum silicate & $\mathrm{Na}_{2} \mathrm{O} \mathrm{SiO}_{2} \mathrm{Al}_{2} \mathrm{O}_{3}$ & 6.83 \\
\hline sodium iron oxid & $\mathrm{Na}_{4} \mathrm{FeO}_{3}$ & 0.93 \\
\hline
\end{tabular}

Table 2. The mineralogical composition of the used floor tile powder mixtures 2. táblázat A hagyományos padlólap porkeverék ásványi összetétele
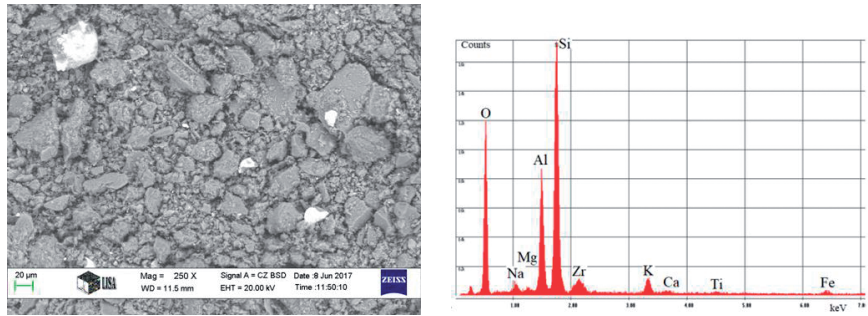

Fig. 1. Micrograph and chemical composition of the conventional pulverized powder of traditional floor tiles

1. ábra A hagyományos padlólap atomizer por mikroszerkezete és kémiai összetétel

On the basis of the earlier experiments with alumina [3437] and zirconia [38-40] of the authors in this research to the conventional floor tiles powder Martoxid KMS-94 alumina (Figure 2) and TZP zircon-dioxide (Figure 3) powders were added in different ratios.
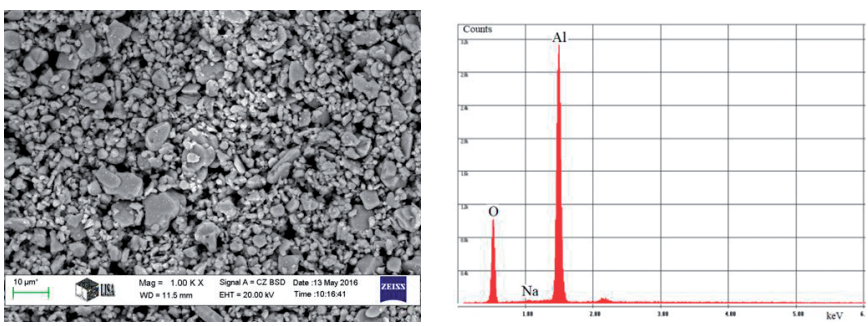

Fig. 2. Micrograph and chemical composition of the Martoxid KMS-94 alumina 2. ábra Martoxid KMS-94 alumínium-oxid mikroszerkezete és kémiai összetétel
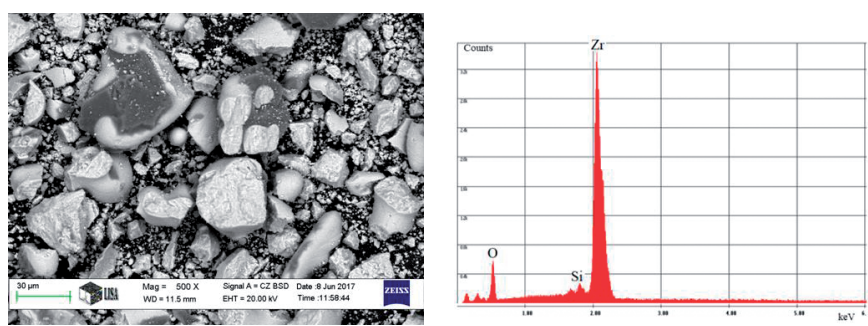

Fig. 3. Micrograph and chemical composition of the TZP zircon-dioxide 3. ábra TZP cirkon-dioxid mikroszerkezete és kémiai összetétel

To increase the mechanical properties to the conventional pulverized floor tiles powders $\mathrm{Al}_{2} \mathrm{O}_{3}(\mathrm{~A})$ and commercial $\mathrm{ZrO}_{2}$ (Z) powders were added in portion of $5 \mathrm{~m} \%, 10 \mathrm{~m} \%, 15 \mathrm{~m} \%$ and $20 \mathrm{~m} \%$ as they are shown in Table 3 .

\begin{tabular}{lccc} 
Mixture sign & $\begin{array}{c}\text { Pulverized } \\
\text { powder }\end{array}$ & $\begin{array}{c}\text { Martoxid KMS- } \\
\text { 94 alumina }\end{array}$ & $\begin{array}{c}\text { TZP } \\
\text { zircon-dioxide }\end{array}$ \\
\hline A5 & 95 & 5 & - \\
\hline A10 & 90 & 10 & - \\
\hline A15 & 85 & 15 & - \\
\hline Z20 & 80 & 20 & - \\
\hline Z10 & 95 & - & 5 \\
\hline Z15 & 90 & - & 10 \\
\hline Z20 & 85 & - & 20 \\
\hline ZA5 & 80 & - & 2.5 \\
\hline ZA10 & 95 & 2.5 & 5 \\
\hline ZA15 & 90 & 5 & 7.5 \\
\hline ZA20 & 85 & 7.5 & 10
\end{tabular}

Table 3. The composition of prepared new mixtures by $m \%$

3. táblázat A készített keverékek összetétele tömegszázalékban [m\%] 
From each mixture of the powders were taken out by $200 \mathrm{~g}$ weights and milled and mixed in a Retch PM 400 planetary ball mill at 200rpm trough 5, 10 and 15 minutes. The so prepared powder mixtures were divided by $10 \mathrm{~g}$ and compacted through one-sided pressing to discs in a cylindrical die cavity with $20 \mathrm{~mm}$ diameter and filling depth of $50 \mathrm{~mm}$ on uniaxial mechanical press at compressing pressures of $158 \mathrm{MPa}$, $196 \mathrm{MPa}, 234 \mathrm{MPa}, 274 \mathrm{MPa}$ and $312 \mathrm{MPa}$. After compacting the geometrical parameters of the discs were measured and determined the "green" density of the specimens. Further these discs were sintered in an electrical laboratory kiln heating up to $1250^{\circ} \mathrm{C}$. When the kiln achieved this temperature the current was switched off and the kiln cooled down freely. The influence of the material composition on the color of the sintered specimens is very well seen in the Figure 4.

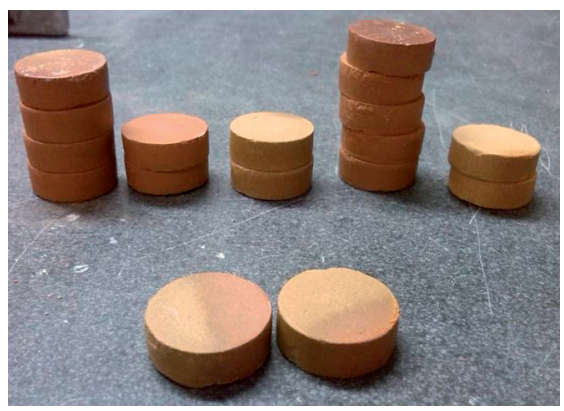

Fig. 4. The sintered at $1250^{\circ} \mathrm{C}$ ceramic disc specimens with different volumes of $\mathrm{Al}_{2} \mathrm{O}_{3}$ and $\mathrm{ZrO}_{2}$ powders in the raw material mixtures

4. ábra A különbözö mennyiségü $\mathrm{Al}_{2} \mathrm{O}_{3}$ és $\mathrm{ZrO}_{2}$ port tartalmazó keverékekböl préselt, majd szinterelt próbatestek

\section{Result and discussions}

During the experiments the green density of the pressed specimens were determined depending on the quantity (portion) of the zirconia and on milling times as function of the compaction pressure. It is obvious from Table 1 that density of zirconia is $5.8 \mathrm{~g} / \mathrm{cm}^{3}$ which is much higher than the density of conventional floor tiles after sintering. So with increasing the portion of TZP powders in the mixtures will increase the green density of the pressed specimens. At the same time the densities of the pressed specimens are increased also with increments the values of compression pressures (Figure 5).

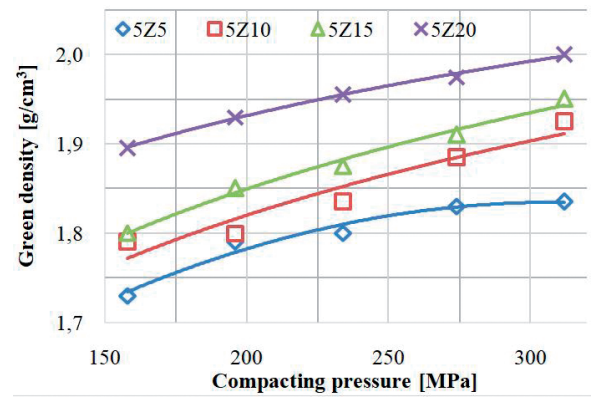

Fig. 5. Influence of volume of $\mathrm{ZrO}_{2}$ powders and compacting pressure on the density of the pressed "green" specimens

5. ábra $\mathrm{A} \mathrm{ZrO}_{2}$ por mennyiségének és a présnyomás hatása a préselt nyers próbatest sürüségére

The influence of milling times also was studied at different compacting pressures (Figure 6). For these 2 different mixtures were prepared with $5 \mathrm{~m} \%$ of zirconia (a) and $5 \mathrm{~m} \%$ of alumina (b) and milled and mixed in a Retch PM 400 planetary ball mill at 200rpm trough 5,10 and 15 minutes. In both cases there is no remarkable different between the pressed green densities after 5 min and 10 min milling but after 15 minutes of milling the densities of the pressed green specimens have decreased considerable. This phenomenon can be explained with intensive mechanochemical processes taking place during fine comminution of the ceramic powders. Thanking to this mechanochemical processes the powder mixtures have very fine grain and pore structures and the submicron particles are electro statically repel each others in the compacting die cavity during and after pressing.

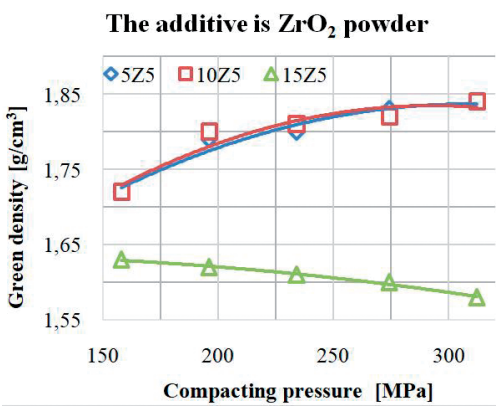

(a)

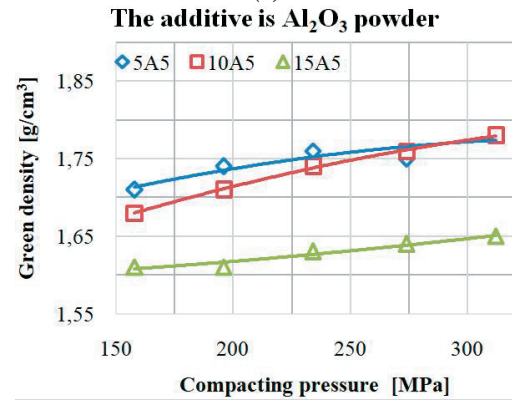

(b)

Fig. 6. Influence of the milling time on density of the pressed specimens depending on compacting pressure

6. ábra Az örlési idő hatása a préselt nyers próbatest sürüségére az alkalmazott présnyomás függvényében

While the green densities of the pressed specimens are followed the densities of the used high-tech ceramics powders after sintering the specimens with TZP zirconia additives had the smallest densities, meanwhile the $\mathrm{ZrO}_{2}+\mathrm{Al}_{2} \mathrm{O}_{3}$ mixed additives have generated the highest sintered densities (Figure 7).

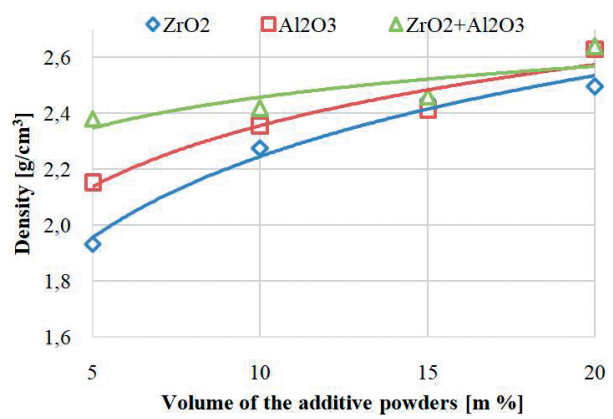

Fig. 7. Influence of volume of $\mathrm{Al}_{2} \mathrm{O}_{3}$ and $\mathrm{ZrO}_{2}$ additive powders on density of the sintered specimens

7. ábra $\mathrm{Az} \mathrm{Al}_{2} \mathrm{O}_{3}$ és $\mathrm{ZrO}_{2}$ por adalékanyag mennyiségének a hatása a szinterelt próbatestek sürüségére 
After the sintering the cylindrical disc specimens were tested on shear strength and pressure strength depending on the containments of zirconia $\left(\mathrm{ZrO}_{2}\right)$ and alumina $\left(\mathrm{Al}_{2} \mathrm{O}_{3}\right)$ powders in the raw material mixtures. The typical destruction and fracture surfaces of the cracked specimens are shown in Figure 8 and the average values of the shear strengths and pressure strengths are shown in Figure 9.

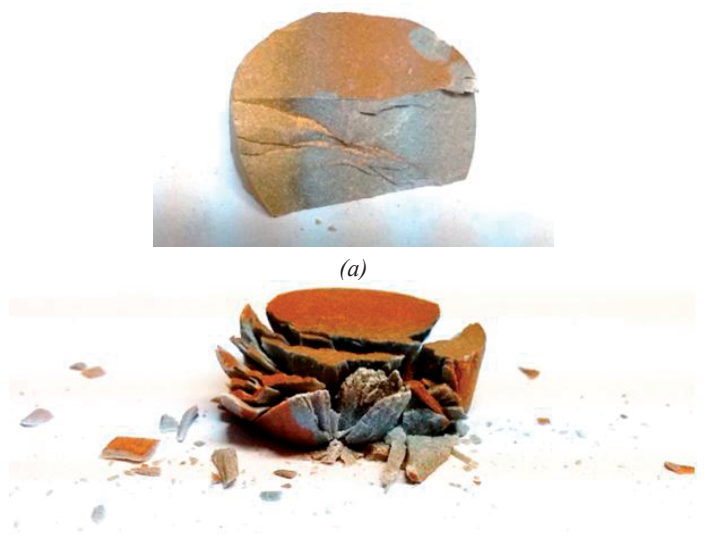

(b)

Fig. 8. Typical fracture surfaces of specimens after shear test (a) and pressure test (b) 8. ábra A próbatestek tipikus törés felületei a nyíró- (a) és a nyomószilárdság vizsgálatok (b) után

It is obvious from the Figure 9 that the volumes of $\mathrm{Al}_{2} \mathrm{O}_{3}$ and $\mathrm{ZrO}_{2}$ raw materials very strong influence both on the shear strengths (a) and pressure strengths (b) of the floor tile specimens sintered at $1250^{\circ} \mathrm{C}$. The highest values of shear strengths were achieved when $5 \mathrm{~m} \%$ zirconia powder was mixed into raw materials and the smallest when $15 \mathrm{~m} \%$ of $\left(\mathrm{Al}_{2} \mathrm{O}_{3}+\mathrm{ZrO}_{2}\right)$ mixed powders were added. The pressure strengths are also minimum when $15 \mathrm{~m} \%$ of $\mathrm{Al}_{2} \mathrm{O}_{3}$ itself and $15 \mathrm{~m} \%$ of $\left(\mathrm{Al}_{2} \mathrm{O}_{3}+\mathrm{ZrO}_{2}\right)$ additives are mixed into the conventional floor tile pulverized powders.

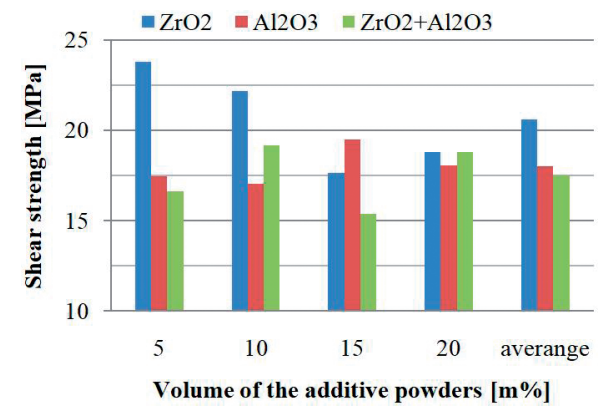

(a)

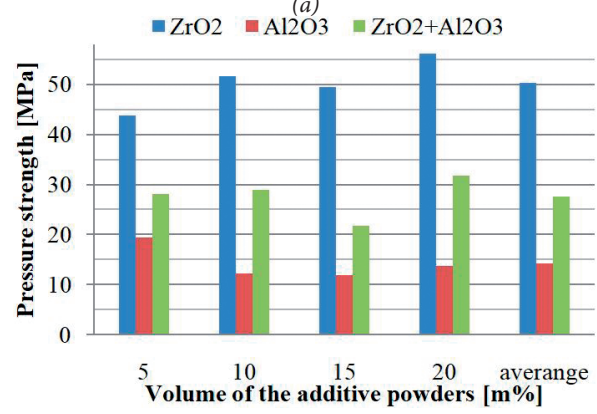

(b)

Fig. 9. The shear strengths (a) and pressure strengths $(b)$ of the sintered specimens made from new raw material compositions

9. ábra A szinterelt próbatestek nyírószilárdsága (a) és nyomószilárdsága (b)
In cases when only alumina powder additives are used the shear strengths of the sintered specimens are higher in each case than their pressure strengths at $10 \mathrm{~m} \%, 15 \mathrm{~m} \%$ and $20 \mathrm{~m} \%$. This phenomenon can be explained that the used $1250^{\circ} \mathrm{C}$ sintering temperature is not high enough when the volume of $\mathrm{Al}_{2} \mathrm{O}_{3}$ is higher than $5 \mathrm{~m} \%$. At the same time the largest pressure strengths of the floor tile specimens made from the new powder mixtures were achieved at volume of $20 \mathrm{~m} \%$ $\mathrm{ZrO}_{2}$ but at $5 \mathrm{~m} \% \mathrm{ZrO}_{2}$ also very good pressure strengths were achieved with average values about $45 \mathrm{MPa}$.

\section{Conclusion}

It is obvious from the realizes experiments that the traditional raw material composition can be used to produce ceramic floor tiles with increased mechanical shear and pressure strengths just adding to its $5 \mathrm{~m} \%$ commercial $\mathrm{ZrO}_{2}$ powders and sintering it at $1250^{\circ} \mathrm{C}$.

\section{Acknowledgements}

The authors thank to IGREX Engineering Service Ltd for support and finance this research.

\section{References}

[1] Tamás, F. (1982): Handbook of Silicate Industry, Müszaki Könyvkiadó, Budapest ISBN 963-10-4365-7 (in Hungarian)

[3] Kunvári, Á. -Tamás, L. -Gömze, L. A. - Liszátzné Helvei, Á. - Simonné Odler, A. - Szabó, M. - Takács, S. - Scharle, Gy. (2001): Ceramic yearbook I ÉTK and MÉASZ, Budapest

[3] Silva, D. A. - Roman, L. M. F. - Fredel, M. C. - Roman, H. R. (1999): Theoretical analysis on the thermal stresses of ceramic tile coating systems, Published in Durability of Building Materials and Components 8. Edited by M A Lacasse and D J Vanier, Ottawa, National Research Council Canada pp. 603-612

[4] da SILVA, Farah Diba - da Costa OLIVEIRA, Felisbela Maria - de SOUZA, Júlio César (2010): Építőanyag-JSBCM 62 (1) 27 http://dx.doi.org/10.14382/epitoanyag-jsbcm.2010.6

[5] Garcia, Eugenio - de Pablos, A. - Bengoechea, M. A. - Guaita, L. - Osendi, Maria Isabel - Miranzo, P. (2011): Ceramics International 37(1):369-375 http://dx.doi.org/10.1016/j.ceramint.2010.09.023

[6] Dana, Kausik - Swapan Kr. Das. (2003) Transactions of the Indian Ceramic Society 62 (3) 158-161. https://doi.org/10.1080/0371750X.2002.10800032

[7] Effting, C. - Folgueras, M. V. - Güths, S. - Alarcon, O. E. (2010): Mat. Res. 13 (3) http://dx.doi.org/10.1590/S1516-14392010000300007

[8] Terjek, A. (2013): IOP Conf. Ser.: Mater. Sci. Eng. 47012017 http://dx.doi.org/10.1088/1757-899X/47/1/012017

[9] Mlinárik, L. - Kopecskó, K. (2013): IOP Conf. Ser.: Mater. Sci. Eng.47 012014 http://dx.doi.org/10.1088/1757-899X/47/1/012014

[10] Kurovics, E. - Buzimov, A. Y. - Gömze, L. A. (2016): IOP Conf. Ser.: Mater. Sci. Eng. 123012058 https://doi.org/10.1088/1757-899X/123/1/012058

[11] Rambaldi, E. - Prete, Francesca - Bignozzi, Maria Chiara (2015): Ceramics International 41 (6) http://dx.doi.org/10.1016/j.ceramint.2015.03.032

[12] Stawiski, Bohdan - Kania, Tomasz (2016) Procedia Engineering 161937 https://doi.org/10.1016/j.proeng.2016.08.662

[13] Kulkov, S. N. - Dedova, E. S. - Pedraza, F. - Erdélyi, J. (2014): ÉpitőanyagJSBCM 66 (2) 35 http://dx.doi.org/10.14382/epitoanyag-jsbcm.2014.7

[14] Zharikov, E. V. - Zaramenskikh, K. S. - Popova, N. A. - Faikov, P. P. Iskhakova, L. D. - Gerke, M. N. - Kutrovskaya, S. V. - Nogtev, D. S. (2011): Glass and Ceramics 6880

[15] Li, J. - Yuan, W. J. - Deng, C. J. - Zhu, H. X. (2013): IOP Conf. Ser.: Mater. Sci. Eng. 47012060 http://dx.doi.org/10.1088/1757-899X/47/1/012060

[16] Sadowski, T. - Kneé, M. - Golewski, P. (2014): Key Engineering Materials 60125 
[17] Sadowski, T. - Golewski, P. (2015): Archives of Metallurgy and Materials 60 (4) 2737

[18] Sadowski, T. - Craciun, E. - Marsavina, L. (2018): AIP Conference Proceedings 1932030036 http://dx.doi.org/10.1063/1.5024186

[19] Gubernat, A. - Stobierski, L. - Labaj, P. (2007): J. Europ. Ceram. Soc. 27781

[20] Kulkov, S. - Savchenko, N. (2008): Épitőanyag-JSBCM 60 (3) 62 http://dx.doi.org/10.14382/epitoanyag-jsbcm.2008.10

[21] Ershova, N. I. - Kelina, I. Y. (2009): Építőanyag-JSBCM 61 (2) 34 http://dx.doi.org/10.14382/epitoanyag-jsbcm.2009.6

[22] Wachtman, J. B. - Cannon, W. R. - Matthewson, M. J. (2009): Mechanical properties of ceramics 2nd Edition Wiley pp1-496

[23] Tkachev, A. G. - Tkacheva, O. N. (2009): Steklo i keramika 66 (2) 15

[24] Ainabayev, A. - Arkhipov, M. - Baideldinova, A. - Omarova, K. Ksandopulo, G. (2013): IOP Conf. Ser.: Mater. Sci. Eng. 47012044 http://dx.doi.org/10.1088/1757-899X/47/1/012044

[25] Csányi, J. - Gömze, L. A. - Kövér, I. Z. (2004): Épitőanyag-JSBCM 56 (3) 103 (in Hungarian) http://dx.doi.org/10.14382/epitoanyag-jsbcm.2004.13

[26] Gömze, L. A. - Gömze, L. N. (2009): Épitőanyag-JSBCM 61 (2) 38 http://dx.doi.org/10.14382/epitoanyag-jsbcm.2009.7

[27] Miranda-Hernández, J. G. - Rocha-Rangel, E. - de la Torre, S. D. (2010): Épitőanyag-JSBCM 62 (1) 2 http://dx.doi.org/10.14382/epitoanyag-jsbcm.2010.1

[28] Kulkov, S. N. - Grigoriev, M. V. (2010): Épitőanyag-JSBCM 62 (3) 66 http://dx.doi.org/10.14382/epitoanyag-jsbcm.2010.13

[29] Kalatur, E. S. - Kozlova, A. V. - Buyakova, S. P. - Kulkov, S. N. (2013): IOP Conf. Ser.: Mater. Sci. Eng. 47012004 http://dx.doi.org/10.1088/1757-899X/47/1/012004

[30] Dedova, E. - Klevtsova, E. - Kulkov, S. (2013): IOP Conf. Ser.: Mater. Sci. Eng. 47012021 http://dx.doi.org/10.1088/1757-899X/47/1/012021

[31] Zhukov, I. - Buyakova, S. P. - Kulkov, S. N. (2016): Épitőanyag-JSBCM 68 (3) 74 http://dx.doi.org/10.14382/epitoanyag-jsbcm.2016.13

[32] Gömze, L. A. - Gömze, L. N. (2017): IOP Conf. Ser.: Mater. Sci. Eng. 175 $012001 \mathrm{http} / / / \mathrm{dx}$.doi.org/10.1088/1757-899X/175/1/012001

[33] Zharikov, E. V. - Kapustin, V. V. - Faikov, P. P. - Popova, N. A. - Barmin, A. A. - Ivanov, A. V. - Rizakhanov, R. N. (2017): IOP Conf. Ser.: Mater. Sci. Eng. 175012065 https://doi.org/10.1088/1757-899X/175/1/012065

[34] Lipusz, Dóra - Isztli, Ákos - Gömze, László A. (2014): Materials Science Forum 812143 https://doi.org/10.4028/www.scientific.net/MSF.812.143

[35] Kurovics, Emese - Shmakova, A. - Kanev, Bronislav - Gömze, László A. (2017): IOP Conf. Ser.: Mater. Sci. Eng. 175012013 https://doi.org/10.1088/1757-899X/175/1/012013
[36] Gömze, László A. (2016): APPLIED MATERIALS SCIENCE i. Compilation of Selected Scientific Papers Publisher: IGREX Ltd., Igrici (Hungary) ISBN: 978-963-12-6600-9

[37] Egész, Ádám - Gömze, László A. (2015): Journal of Physics Conference Series 602 (1) https://doi.org/10.1088/1742-6596/602/1/012023

[38] Savchenko, Nickolai - Sevostyanova, Irina - Sablina, Tatiana - Gömze, László - Kulkov, Sergei (2014): AIP Conference Proceedings 1623547 https://doi.org/10.1063/1.4899003

[39] Kulkov, S. N. - Buyakova, S. - Gömze, L. A. (2017): J. Phys.: Conf. Ser. 790 012015 http://iopscience.iop.org/1742-6596/790/1/012015

[40] Dedova, E. S. - Shutilova, E. S. - Geber, R. - Gömze, L. A. - Kulkov, S. N. (2016): IOP Conf. Ser.: Mater. Sci. Eng. 140012007 http://iopscience.iop.org/1757-899X/140/1/012007

$\underline{\text { Ref.: }}$

Gömze, László A. - Kulkov, Sergei N. - Kurovics, Emese - Buyakov, Ales S. - Buzimov, Alexandr Y. - Grigoriev, Mihail V. Kanev, Bronislav I. - Kolmakova, Tatiana V. - Levkov, Ruslan V. - Sitkevich, Sergey A.: Development ceramic floor tiles with increased shear and pressure strengths

Építőanyag - Journal of Silicate Based and Composite Materials, Vol. 70, No. 1 (2018), 13-17. p.

https://doi.org/10.14382/epitoanyag-jsbcm.2018.3

Növelt nyíró- és nyomószilárdságú kerámia padlólapok fejlesztése

Jelen kutatás során tanulmányozták és leírták az alumínium-oxid és a cirkon-dioxid hatását a hagyományos kerámia padlólapok fizikai és mechanikai tulajdonságaira. Különbözô nyersanyag összetételek vizsgálata után a szerzók megállapították, hogya kereskedelmi forgalomban levô $\mathrm{ZrO}_{2}$ por 5 m\%-ban történố hozzáadásával jelentôsen növelhetố a padlólapok nyíró- és nyomószilárdsága. Az ilyen új, megnövelt mechanikai szilárdsággal rendelkezô padlólapok alkalmasak lehetnek a tej-, hús-, élelmiszerés más iparágakban történő felhasználásra.

Kulcsszavak: alumínium-oxid, kerámiák, préselés, súrúség, padlólapok, keverékek, porok, cirkon-dioxid

\section{$4^{\text {th }}$ International Conference on} Geramicsand Composite Materials

\section{May 14-15, 2018 Rome, ltaly}

Conference Highlights:

- Ceramics and Glasses

- Advanced Ceramic Materials

- Ceramics and Composites

- Composite Materials

- Ceramic Coatings

- Advanced Materials and Technologies

- Materials and Innovative Processing Ideas
- Nanostructured Ceramics

- Porous Ceramics

- Sintering

- Crystalline Materials

- Ceramics Applications

- Bioceramics and Medical Applications

- Functional Ceramics and Inorganics 